\title{
Diversity of the genus Brasilonema (Nostocales, Cyanobacteria) in plant nurseries of central Florida (USA) with the description of three new species: B. fioreae sp. nov., B. santannae sp. nov. and B. wernerae sp. nov.
}

\author{
Maximiliano Barbosa ${ }^{1}$, David E. Berthold ${ }^{1}$, Forrest W. Lefler ${ }^{1} \&$ H. Dail \\ LAUGHINGHOUSE IV ${ }^{1,2^{*}}$
}

\author{
${ }^{1}$ Agronomy Department, Fort Lauderdale Research and Education Center, University of Florida / IFAS, 3205 \\ College Avenue, Davie, Florida 33314, USA; *Corresponding author e-mail: hlaughinghouse@ufl.edu, Tel: \\ +1-954-577-6382, ORCID\#: 0000-0003-1018-6948 \\ ${ }^{2}$ Department of Botany, National Museum of Natural History, Smithsonian Institution, PO Box 37012, Washington, \\ DC 20013, USA
}

\begin{abstract}
Florida is a diverse region that supports abundant cyanobacterial diversity, especially in terrestrial environments. To exploit this environment for cyanobacterial diversity, several greenhouses from central Florida were sampled to identify common nuisance and contaminating algae. Most of the algae observed were mat forming, covering nursery pots, plants, and equipment which were macro- and microscopically morphologically analogous to Brasilonema. Although macroscopic thallus morphology was similar among the samples, microscopic morphological characteristics such as size, color, and sheath formation were disparate. To uncover the cryptic diversity, mats were processed for species isolation, culture, and molecular taxonomic identification. A total of eleven Brasilonema strains were isolated into culture and systematically identified using 16S rRNA and 16S-23S rRNA ITS sequences. Based on morphology and molecular data, five species of Brasilonema were found and three are new to science: $B$. fioreae, B. santannae, and B. wernerae.
\end{abstract}

Key words: Scytonemataceae, 16S rRNA, 16S-23S rRNA ITS, subtropical, aerophytic, terrestrial, greenhouse, diversity

\section{INTRODUCTION}

Cyanobacteria have adapted to most habitats on the planet and are amongst the most abundant and geographically widespread groups of phototrophic bacteria (WHITTON \& Pоттs 2012). These microorganisms occur ubiquitously in aquatic habitats but are also an ecologically important component of terrestrial and aerophytic environments, where they grow on various substrates such as wood, soil, and rocks as biofilms, mats and within biological soil crusts (GAMA JR. et al. 2014; Miscoe et al. 2016; PesSI et al. 2016; Pietrasiak et al. 2019). Such communities have vital roles in the ecosystem where they sequester carbon, consolidate soil particles, and provide important resources for soil fertility. Yet, the diversity of terrestrial and aerophytic cyanobacteria remains relatively understudied when compared to aquatic habitats, though in recent years there has been an increase in newly described cyanobacterial taxa from these environments using polyphasic methods (e.g., Fiore et al. 2007; KomÁreK et al. 2014; Miscoe et al. 2016; Pietrasiak et al. 2019). The genus Brasilonema Fiore et al. (2007: 794) is an aerophytic and subaerophytic nostocalean genus of cyanobacteria found in subtropical and tropical habitats growing in phytotelmata, epiphytic on plants and tree bark, and on stones, rocks and wet walls (FIORE et al. 2007; Aguiar et al. 2008; SAnt'Anna et al. 2011). The genus was originally isolated and described from (sub) tropical Brazil being separated from Scytonema (FIORE et al. 2007). Since then, several species have been described from natural (sub)tropical environments and greenhouses (see FIORE et al. 2007; A GUIAR et al. 2008; SANT'AnNa et al. 2011; VACCARINo \& Johansen 2012; BECERRA-AbSAlón et al. 2013; RodArte et al. 2014; Villanueva et al. 2018, 2019; Montoya et al., 2019; RomANENKo et al. 2020).

Brasilonema is characterized by macroscopic filaments with a wide range of coloration - typically dark green, violet, or dark brown - abundant false branching, colorless sheaths, and are commonly epiphytic. This genus is within the family Scytonemataceae and also characterized by the presence of heterocytes and cell division in a single plane. Moreover, Brasilonema can be distinguished from other taxa by the presence of erect, 
fasciculate thalli, presence of vacuole-like spaces in the cytoplasm center, and subaerophytic habitat.

Combining classical morphology and modern molecular scrutiny (polyphasic approach) is a powerful tool to delimitate cyanobacteria, especially those with cryptic tendencies, and is essential in describing cyanobacterial taxa (KомÁREK 2016; WiLmotte et al. 2017; DvořÁK et al. 2018). During a study on the diversity and management of nuisance algae and cyanobacteria in greenhouses of central Florida, several Brasilonema-like species were observed. In order to shed light on this diversity, a morphological and molecular assessment was carried out on these specimens. Using light microscopy, 16S rRNA gene and 16S-23S rRNA internal transcribed spacer (ITS) phylogenies and pairwise distances, and 16S-23S rRNA ITS secondary structures, we found five morphologically and phylogenetically distinct species of Brasilonema with three being new to science: $B$. fioreae D.E. Berthold, M. Barbosa, Lefler et Laughinghouse sp. nov., B. octagenarum Aguiar et al., B. santannae D.E. Berthold, M. Barbosa, Lefler et Laughinghouse sp. nov., B. tolantongensis Becerra-Absalón et Montejano, and B. wernerae D.E. Berthold, M. Barbosa, Lefler et Laughinghouse sp. nov.

\section{Materials ANd Methods}

Isolation, culturing and morphological analyses. Field samples were collected in March 2018 in several greenhouses and nursey production areas (walls, floors, and containers) with nuisance cyanobacteria located at the Mid-Florida Research and Education Center (MREC; 28 38'14.9'N, 81 ${ }^{\circ} 32^{\prime} 54.8^{\prime \prime} \mathrm{W}$ ), University of Florida/IFAS in Apopka, FL (USA). Samples were taken from observable algal growth on grounds, walls, and production containers (Fig. 1). Cyanobacteria were isolated using micromanipulation onto solid BG-11 media ( $3 \%$ Agar), cultured using BG-11 liquid media and incubated at $25^{\circ} \mathrm{C}$ on a 12:12-h light:dark cycle under cool white $(6500 \mathrm{~K})$ fluorescent lighting $\left(100 \mu \mathrm{Es}^{-1} \cdot \mathrm{cm}^{-2}\right)$. Cyanobacterial isolates were treated with cycloheximide (Sigma; $300 \mu \mathrm{g} . \mathrm{ml}^{-1}$ ) to remove contaminating eukaryotes.

Morphological assessment was carried out by measuring filament and trichome diameter, thallus and sheath morphology and coloration, cell content and color, length and width of heterocytes, branching, and hormogonia development. Cyanobacteria were measured and imaged using either an Epifluorescent microscope (Amscope, XYL-606) or an Olympus (BX51) differential interference contrast (DIC) microscope with accompanying camera and imaging software. Cyanobacterial isolates are maintained live in the BLCC (Ft. Lauderdale Research and Education Center, University of Florida /IFAS, Davie, FL, USA) and in the BCCM/ULC (Université de Liège, Liège, Belgium), while type material (metabolically inactivate), both dried and preserved ( $4 \%$ formaldehyde), of novel species are deposited in the US National Herbarium (National Museum of Natural History, Smithsonian Institution, Washington DC, USA). Information on isolation source, date, location coordinates, and accession numbers of cyanobacterial strains are summarized in Supplementary Table 1.
Molecular Analyses. Approximately $100 \mathrm{mg}$ of fresh unicyanobacterial cultures were used for DNA extraction using a DNeasy PowerSoil Kit (Qiagen, USA). The 16S rRNA gene and the 16S-23S rRNA internal transcribed spacer (ITS) region were amplified by polymerase chain reaction (PCR) on a ProFlex (Applied Biosystems) thermocycler. Primers 359F and $1487 \mathrm{R}$ were used for the $16 \mathrm{~S}$ rRNA gene and primers $1337 \mathrm{~F}$ and 23S30R for the 16S-23S rRNA ITS region (WILmotte et al. 1993; NüBEL et al. 1997). PCR protocols were followed according to BERTHOLD et al. (2020). Both genes were amplified using a GoTaq ${ }^{\circledR}$ PCR Core Systems kit (Promega, USA). Amplified DNA was purified using QIAquick PCR Purification Kit (Qiagen, USA) and visualized on a $1 \%$ agarose gel. The 16S rRNA amplified products were then sequenced using Sanger Sequencing (Eurofins, KY, USA).

PCR products of the $16 \mathrm{~S}-23 \mathrm{~S}$ rRNA ITS region were cloned using TOP10 chemically competent cells (TOPO-TA, Invitrogen) following manufacturer protocols. Cloned plasmids were extracted from clone libraries using a PureLink Quick Plasmid Miniprep Kit (Invitrogen). Plasmids containing inserts were sent for sequencing using Sanger sequencing (BigDye Terminator v3.1 (Applied Biosystems), Eurofins, KY, USA). Sequences for both the 16S rRNA gene and 16S-23S rRNA ITS region are deposited in GenBank (National Center for Biotechnology Information, NCBI) and found in Supplementary Table S1. The software MEGA (v10.1.7; KumAR et al. 2018) was used to edit and proofread sequences.

Phylogenetic Analyses. Phylogenetic analyses were based on a $\sim 1040$ bp fragment of the 16S rRNA gene. Closely related taxa chosen for analysis were identified using BLAST (Basic Local Alignment Tool, NCBI) and previous literature on the genus, including species of the genera Calothrix, Rivularia, and Scytonema, as well as additional Nostocales with Gloeobacter violaceous PCC7421 (NR074282) as an outgroup. A total of 70 sequences were used in the final analysis, consisting of 59 OTUs retrieved from GenBank, including G. violaceous, and our 11 isolated strains. The initial alignment was constructed using MUSCLE on MEGA (v10.1.17) (EDGAR 2004), and the sequences were manually proofread and edited according to conserved regions. The best-fit substitution model was determined using jModelTest in MEGA (STETCHER et al. 2020). Maximum likelihood (ML) analysis was carried out using the model $\mathrm{K} 2+\mathrm{G}+\mathrm{I}$ with 1,000 bootstrap resampling replicates using MEGA. Bayesian analysis (BS) was conducted with MrBayes using $1.0 \times 10^{6}$ generation, a 0.25 burn-in rate, and resampling every 100 generations, through the CIPRES network (v.3.3) (GUINDON \& GASCUEL 2003; RonQUisT \& HUELSENBECK 2003; Miller et al. 2010).

The 16S-23 rRNA ITS region ( 590-880 bp) phylogeny was constructed following the previously discussed methods above for Bayesian analysis; the ML analysis was carried out using $\mathrm{HYK}+\mathrm{G}$ model with 1000 bootstraps using our 11 isolates and 5 available $16 \mathrm{~S}-23 \mathrm{~S}$ rRNA ITS sequences within the genus Brasilonema. The phylogenetic tree was constructed using operons with and without tRNA. Secondary structures of the 16S-23S rRNA ITS region were determined for our isolates and compared to previously published sequences. The secondary structures were delineated, distinguishing operons with and without tRNA based on the presence of conserved tRNA bases and folded using Mfold web server (ZUKER 2003). The folded structures were downloaded from the web server and edited with Adobe Illustrator (ver. 24.1.1). 


\section{RESULTS}

\section{Taxonomic Descriptions}

Class: Cyanophyceae

Order: Nostocales

Family: Scytonemataceae

Brasilonema fioreae D.E. Berthold, M. Barbosa, Lefler et Laughinghouse sp. nov. (Fig. 2)

Description: Thallus dense, erect, forest green in color, with heteropolar trichomes. Filaments with sheath, fasciculate, straight or bent, slightly tapering, with Scytonemataceae-type false branching. Filaments 15.7-22.9 $\mu \mathrm{m}$ wide $(19.5 \pm 2.1 \mu \mathrm{m})$. Sheath thin, thicker near branching, hyaline, $3.2 \pm 1.2 \mu \mathrm{m}$ wide. Trichomes cylindrical, straight, slightly constricted at cross-walls, 12.4-20.2 $\mu \mathrm{m}$ wide $(16.4 \pm 1.8 \mu \mathrm{m})$. Cells somewhat isodiametric, light green to dark grey or orange in color, granulated, highly vacuolated, $12.4-20.2 \mu \mathrm{m}$ wide $\times$ 5.1-10.1 $\mu \mathrm{m}$ long. Apical cells rounded, calyptra not present. Heterocytes common, intercalary, square and sometimes flattened, $12.1-18.3 \mu \mathrm{m}$ wide $\times 5.3-11.7 \mu \mathrm{m}$ long. Akinetes not present. Reproduction by motile and aerosolizing hormogonia.

Holotype: US227704 (US National Herbarium, Smithsonian Institution, Washington, DC, USA; dried material in a metabolically inactive state from reference strain BLCC-T72).

Type locality: Growing in greenhouses attached to walls, rocks, and planters, Apopka, FL, USA; $28^{\circ} 38^{\prime} 18.8^{\prime \prime} \mathrm{N}$, $81^{\circ} 32^{\prime} 53.9^{\prime \prime} \mathrm{W}$.

Habitat: Subaerophytic and terrestrial.

Etymology: "fioreae" (L.) is an epithet that honors Dr. Marli de Fátima Fiore for her dedication and work on cyanobacterial systematics, genetics, and bioactive compounds.

Reference strain: BLCC-T72 (University of Florida, Davie, FL, USA) and ULC548 (BCCM, University of Liège, Liège, Belgium).

Materials analyzed: strains BLCC-T72, BLCC-T73, BLCC-T83, and BLCC-T86.

GenBank accession numbers: 16S rRNA: MT396512, MT396513, MT396514 and MT396516; 16S-23S rRNA ITS: MT396523, MT396524, MT396525 and MT396527.

Brasilonema santannae D.E. Berthold, M. Barbosa, Lefler et Laughinghouse sp. nov. (Fig. 3)

Description: Thallus dense, erect, green to dark grey in color. Filaments often fasciculate, straight or bent, slightly tapering, with Scytonemataceae-type falsebranching, 19.2-26.1 $\mu \mathrm{m}$ wide $(22.9 \pm 2.2 \mu \mathrm{m})$. Sheath thin, hyaline to yellow brown, often encrusted, $4.7 \pm 1.3$ $\mu \mathrm{m}$ wide. Trichomes cylindrical, straight to flexuous, slightly constricted at cross-walls, 13.0-21.4 $\mu \mathrm{m}$ wide $(18.2 \pm 2.4 \mu \mathrm{m})$. Cells isodiametric, sometimes wider than long, green to reddish brown in color, granulated, highly vacuolated, $13.0-21.4 \mu \mathrm{m}$ wide $\times 5.9-13.4 \mu \mathrm{m}$ long. Apical cells are rounded and blunt, calyptra present. Heterocytes common, intercalary, square and sometimes elongated, 20.3-26.1 $\mu \mathrm{m}$ wide $\times 12.4-18.2 \mu \mathrm{m}$ long. Akinetes not present. Hormogonia rare or not present.

Holotype: US227696 (US National Herbarium, Smithsonian Institution, Washington, DC, USA; dried material in a metabolically inactive state from reference strain BLCC-T43).

Type locality: Attached to walls, rocks and planters in greenhouses, Apopka, FL, USA (283' $18.8^{\prime \prime} \mathrm{N}$, 8132'53.9"W).

Habitat: Subaerophytic and terrestrial.

Etymology: "santannae" (L.) is an epithet that honors Dr. Celia Leite Sant'Anna for her dedication and work in cyanobacterial systematics and taxonomy.

Reference strain: BLCC-T43 (University of Florida, Davie, FL, USA) and ULC544 (BCCM, University of Liège, Liège, Belgium).

Materials analyzed: strains BLCC-T43 and BLCC-T64. GenBank accession numbers: 16S rRNA: MT396506 and MT396507; 16S-23S rRNA ITS: MT396517 and MT396518.

Brasilonema wernerae D.E. Berthold, M. Barbosa, Lefler et Laughinghouse sp. nov. (Fig. 4)

Description: Thallus dense, erect, composed of heteropolar trichomes, olive green in color. Filaments often fasciculate, straight or bent, slightly tapering, with Scytonemataceae-type false-branching, 24.1-29.9 $\mu \mathrm{m}$ wide $(26.6 \pm 2.1 \mu \mathrm{m})$. Sheath occasionally thick, extends past filament, hyaline, $4.5 \pm 1.5 \mu \mathrm{m}$ wide. Trichomes cylindrical, straight, and slightly constricted at cross-walls, $19-26.7 \mu \mathrm{m}$ wide $(22.6 \pm 2.6 \mu \mathrm{m})$. Cells isodiametric, sometimes wider than long, light brown to reddish brown in color, granulated, highly vacuolated, 19.0-26.7 $\mu \mathrm{m}$ wide $\times 7.6-14.4 \mu \mathrm{m}$ long. Apical cells are rounded, calyptra is present. Heterocytes are common, intercalary, square and elongated, 18.6-26.5 $\mu \mathrm{m}$ wide $\times$ 6.3-17.6 $\mu \mathrm{m}$ long. Akinetes not present. Reproduction by hormogonia.

Holotype: US227697 (US National Herbarium, Smithsonian Institution, Washington, DC, USA; dried material in a metabolically inactive state from reference strain BLCC-T49).

Type locality: Growing within and outside of greenhouses attached to walls, rocks, and planters, Apopka, FL, USA (28॰38'18.8"N, 81³2'53.9"W).

Habitat: Subaerophytic and terrestrial.

Etymology: "wernerae" (L.) is an epithet that honors Dr. Vera Regina Werner for her dedication and work on the study of cyanobacterial systematics and taxonomy. Reference strain: BLCC-T49 (University of Florida, Davie, FL, USA) and ULC573 (BCCM, University of Liège, Liège, Belgium).

Materials analyzed: strain BLCC-T49.

GenBank accession numbers: 16S rRNA: MT396508; 16S-23S rRNA ITS: MT396519. 


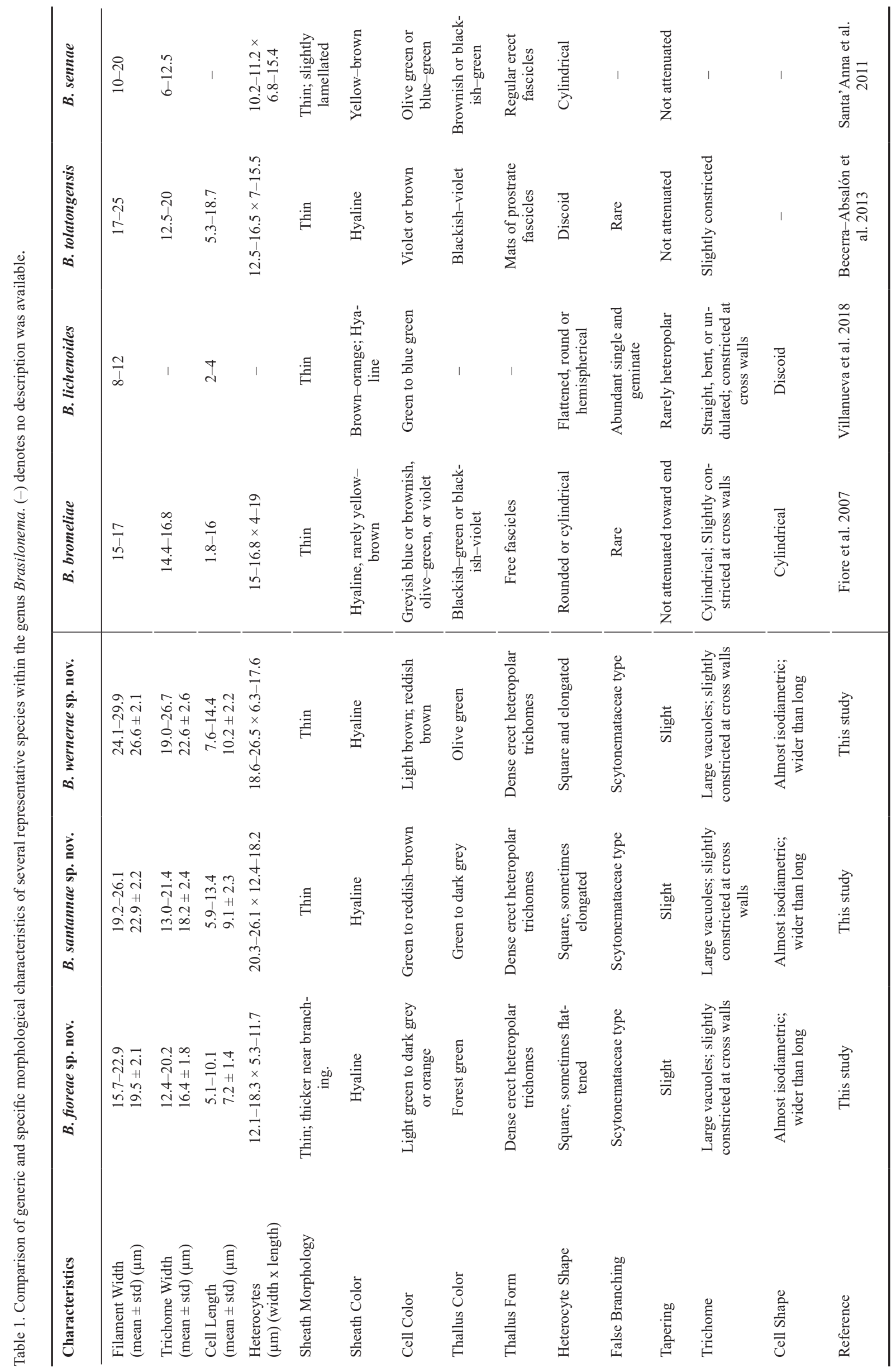




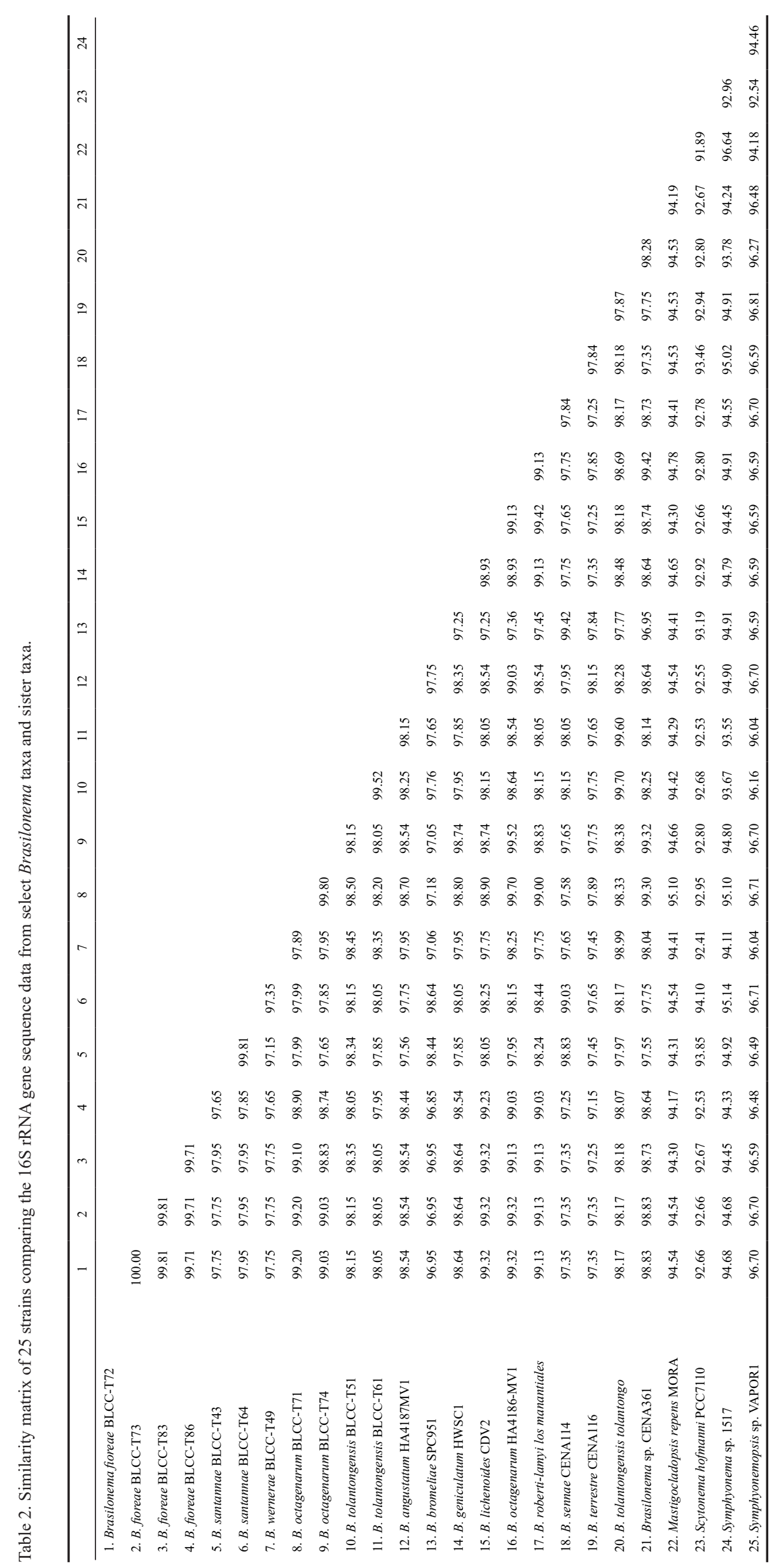




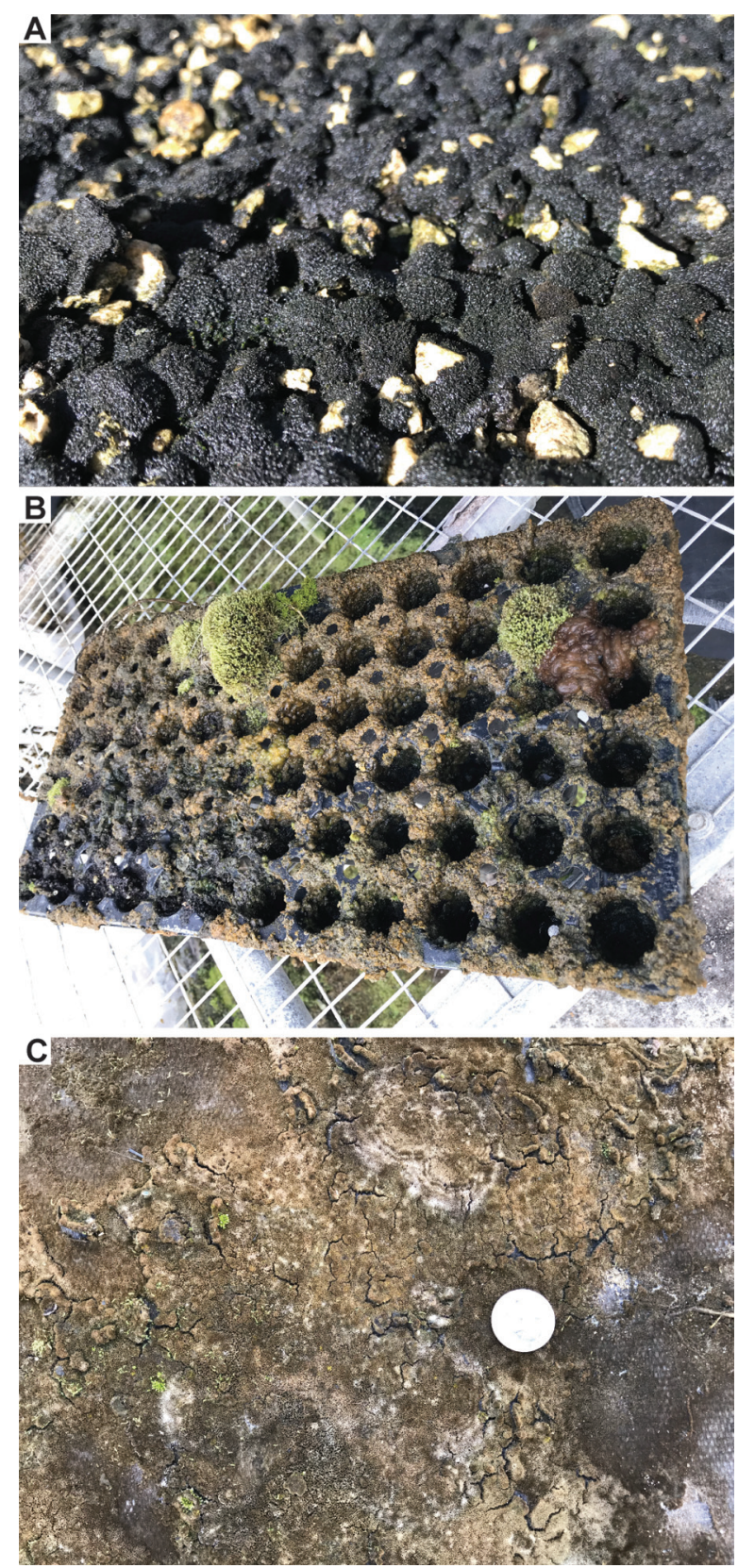

Fig. 1. Field images of mixed algal mats composed of Brasilonema and other cyanobacteria and algae growing on various greenhouse surfaces including: (A) indoor gravel; (B) plastic nursery pot containers; and $(\mathrm{C})$ uncovered tarp material. American quarter (diameter= $19.05 \mathrm{~mm})$ is shown for size.

\section{Brasilonema tolantongensis Becerra-Absalón et Montejano (Fig. 5)}

Comment: Our material fits the original morphological description of this species in BECERRA-ABSALón et al. (2013) and clusters together with B. tolantongensis in the phylogenetic tree.

Thallus dense, erect, composed of heteropolar trichomes, gold to dark brown in color. Filaments often fasciculate straight or bent, slightly tapering, with Scytonemataceae-type false branching, 18.7-28.1 $\mu \mathrm{m}$ wide $(22.8 \pm 2.8 \mu \mathrm{m})$. Sheath thin, extends past filament, thicker near branching, hyaline, $5.1 \pm 1.7 \mu \mathrm{m}$ wide.
Trichomes cylindrical, straight, and slightly constricted at cross-walls, $13.7-23.3 \mu \mathrm{m}$ wide $(17.6 \pm 2.2 \mu \mathrm{m})$. Cells somewhat isodiametric, reddish green to brown in color, granulated, highly vacuolated, 13.7-23.3 $\mu \mathrm{m}$ wide $\times 4.4-12.8 \mu \mathrm{m}$ long. Apical cells rounded, calyptra present. Heterocytes common, intercalary, square to elongated, sometimes flattened, 18.7-23.1 $\mu \mathrm{m}$ wide $\times$ 11.6-13.2 $\mu \mathrm{m}$ long. Akinetes not present. Reproduction by motile and aerosolizing hormogonia.

Material examined: strains BLCC-T51 and BLCC-T61. Dried and preserved examined material: US227698 and US227700.

GenBank accession numbers: 16S rRNA gene: MT396509 and MT396510. 16S-23S rRNA ITS region: MT396520 and MT396521.

Brasilonema octagenarum Aguiar, Fiore, Franco, Ventrella, Lorenzi, Vanetti et Alfenas (Fig. 6)

Comment: Our material fits the original morphological description of this species in AgUIAR et al. (2008) and clusters together with $B$. octagenarum in the phylogenetic tree.

Thallus dense, erect, composed of heteropolar trichomes, reddish green to maroon in color. Filaments often in fascicles, straight or bent, slightly tapering, with Tolypothrichaceae-type false-branching, 14.5-24.1 $\mu \mathrm{m}$ wide $(18.3 \pm 2.4 \mu \mathrm{m})$. Sheath thin, extends past filament, thicker near branching, hyaline, $3.4 \pm 1.1 \mu \mathrm{m}$ wide. Trichomes cylindrical, straight, slightly constricted at cross-walls, 12.1-20.9 $\mu \mathrm{m}$ wide (14.9 $\pm 2.2 \mu \mathrm{m})$. Cells isodiametric, light green to dark brown in color, granulated, highly vacuolated, $12.1-20.9 \mu \mathrm{m}$ wide $\times$ 5.8-12 $\mu \mathrm{m}$ long. Apical cells rounded, calyptra present. Heterocytes common, intercalary, square, 12.7-19.8 $\mu \mathrm{m}$ wide $\times 5.7-9.9 \mu \mathrm{m}$ long. Akinetes not present. Hormogonia present.

Material examined: strains BLCC-T71 and BLCC-T74. Dried and preserved examined material: US227703 and US227706.

GenBank accession numbers: 16S rRNA gene: MT396511 and MT396515. 16S-23S rRNA ITS region: MT396522 and MT396526.

\section{Morphological and phylogenetic 16S rRNA gene analyses}

The eleven isolates presented in this work fit the generic morphological description of Brasilonema with macroscopic velvet-like, dense masses of erect thalli, filaments with sheath, and the presence of large vacuoles in the cells (Table 1, Table S2). Furthermore, the isolates were collected from common Brasilonema habitats including subaerophytic environments and attached to substrates such as wet soil, gravel, and artificial surfaces. Five distinct species were observed and isolated, three being novel to science based on morphology, the 16S rRNA gene and 16S-23S rRNA ITS region phylogenies and genetic similarities (p-distance), and the 16S-23S ITS secondary structure. 
A
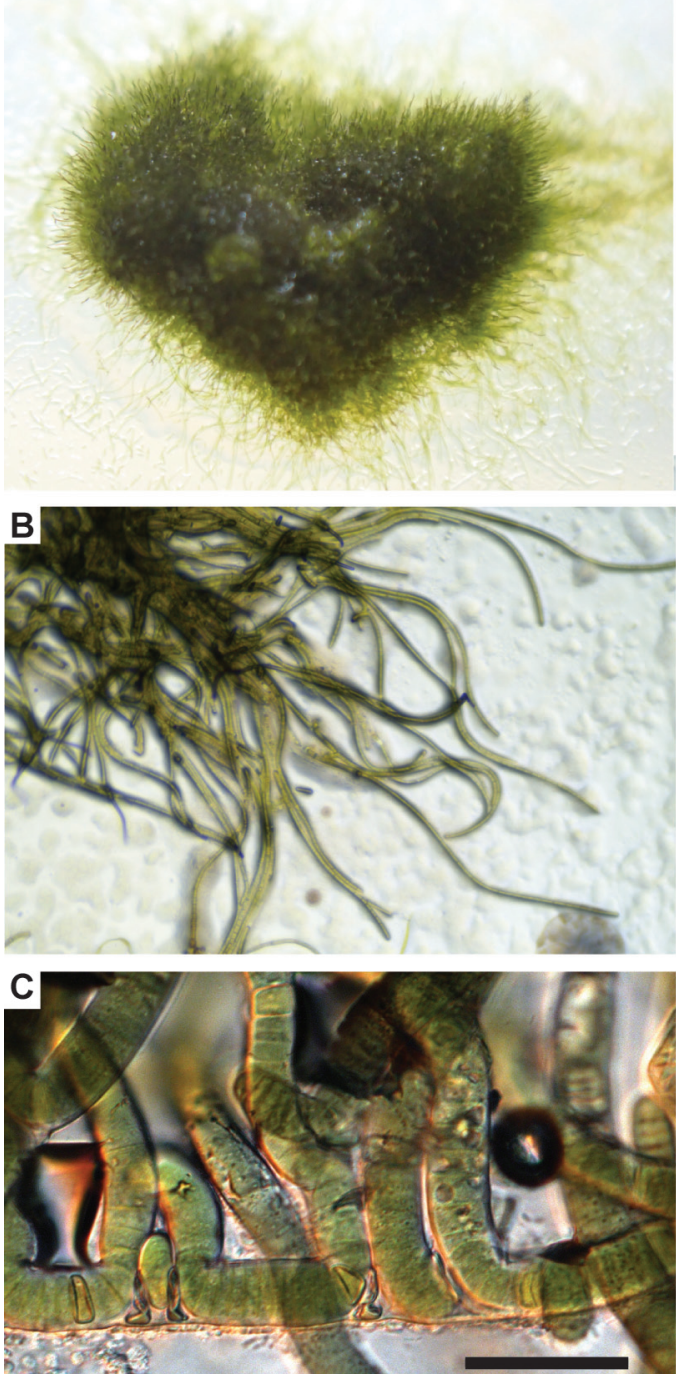
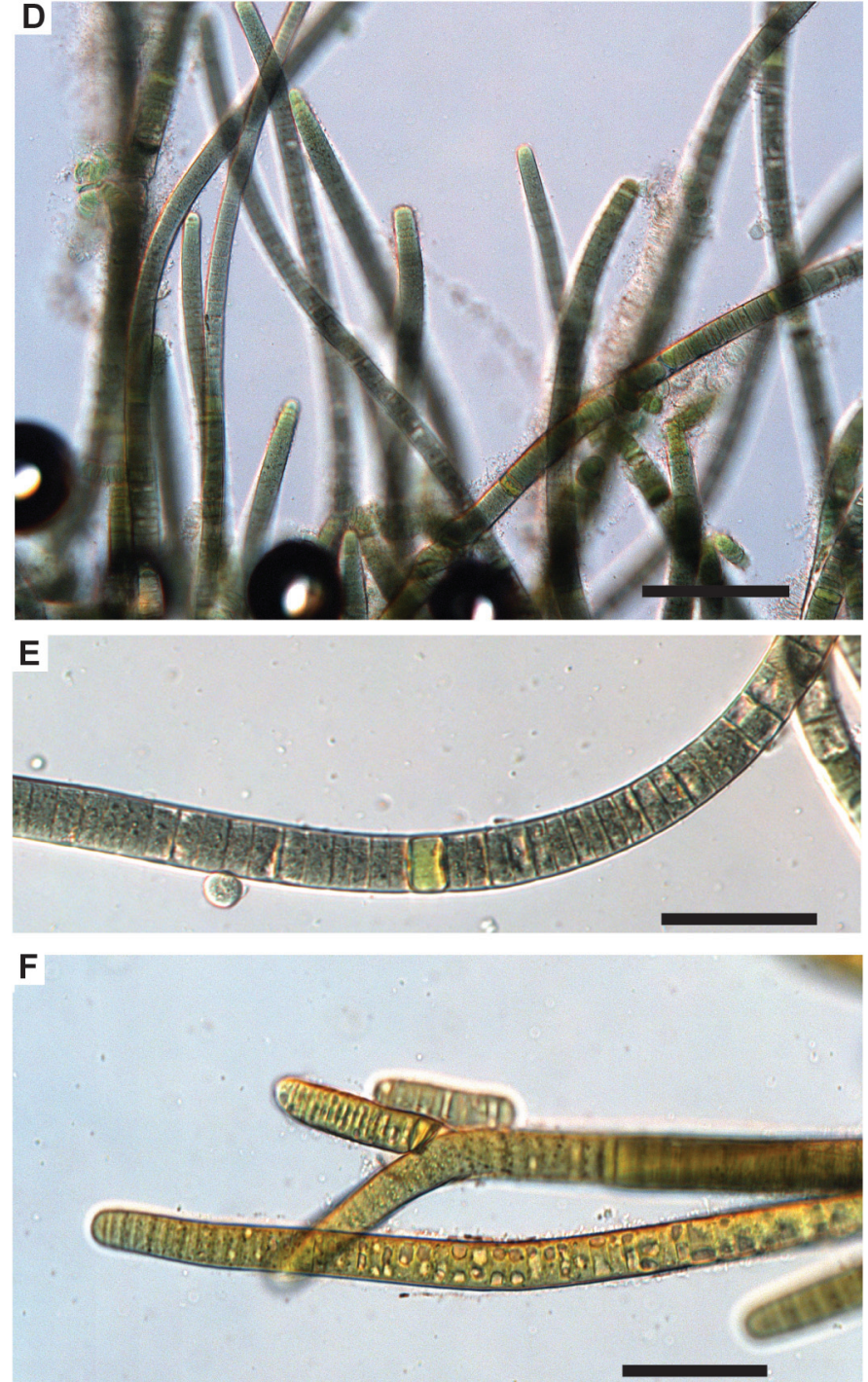

Fig. 2. Images of Brasilonema fioreae sp. nov. (reference strain BLCC-T72) showing primary morphological characteristics including: (A-B) macroscopic thallus with densely fasciculate filament growth on agar; (C) Scytonemataceae-type false branching; (D-E) intercalary heterocytes; (F) hyaline sheath formation and isopolar motile hormogonia. Scale bars $100 \mu \mathrm{m}(\mathrm{D}), 50 \mu \mathrm{m}(\mathrm{C}, \mathrm{E}, \mathrm{F})$.

The 16S rRNA gene phylogenetic analyses clearly showed that our 11 isolates were grouped in the genus Brasilonema (Fig. 7; BS: 1.0, ML: 87). The Bayesian analysis produced a tree with the most supported nodes and is presented with ML bootstrap support values added (Fig. 7). Within Brasilonema, the eleven isolates represented five distinct species. Of these five, two are established and previously described species including B. octagenarum (strains BLCC-T71 and BLCC-T74 (BS: 0.96)) and B. tolantongensis (strains BLCC-T51 and BLCC-T61 (BS: 1.0, ML: 94)). Besides these four strains, the remaining seven Brasilonema strains formed three novel clades within Brasilonema with high support, which are described as the novel species $B$. fioreae, $B$. santannae, and B. wernerae. Brasilonema fioreae is sister to the undescribed Brasilonema sp. KEN MK50, Brasilonema sp. CR65A, Brasilonema sp. BZ HDL 007, and Brasilonema sp. CR64B with high support (BS: 0.71). Brasilonema santannae was most closely related to $B$. sennae (Komárek) Sant'Anna et Komárek and $B$. bromeliae Fiore et al. with high support (BS: 0.75 ). Brasilonema wernerae is sister to B. tolantongensis (BS: 1.0).

Brasilonema fioreae sp. nov. (BLCC-T72, BLCC-T73, BLCC-T83, and BLCC-T86) demonstrated typical characteristics of Brasilonema. The species grows attached to substrates and forms dense erect fascicles (Fig. 2A). The trichomes have intercalary heterocytes, possess sheaths that are often hyaline, or colorless, and form vacuole-like structures (Figs. 2D, E). The species has Scytonemataceae-type false branching (Fig. 2C) with isopolar hormogonia that were observed to be motile and aerosolize (Fig. 2F). The extensive formation of vacuole-like structures within the cells of $B$. fioreae are a diacritical marker that distinguishes it from other Brasilonema species. Moreover, the larger dimensions of B. fioreae compared to other closely related Brasilonema taxa further highlights differences between species 

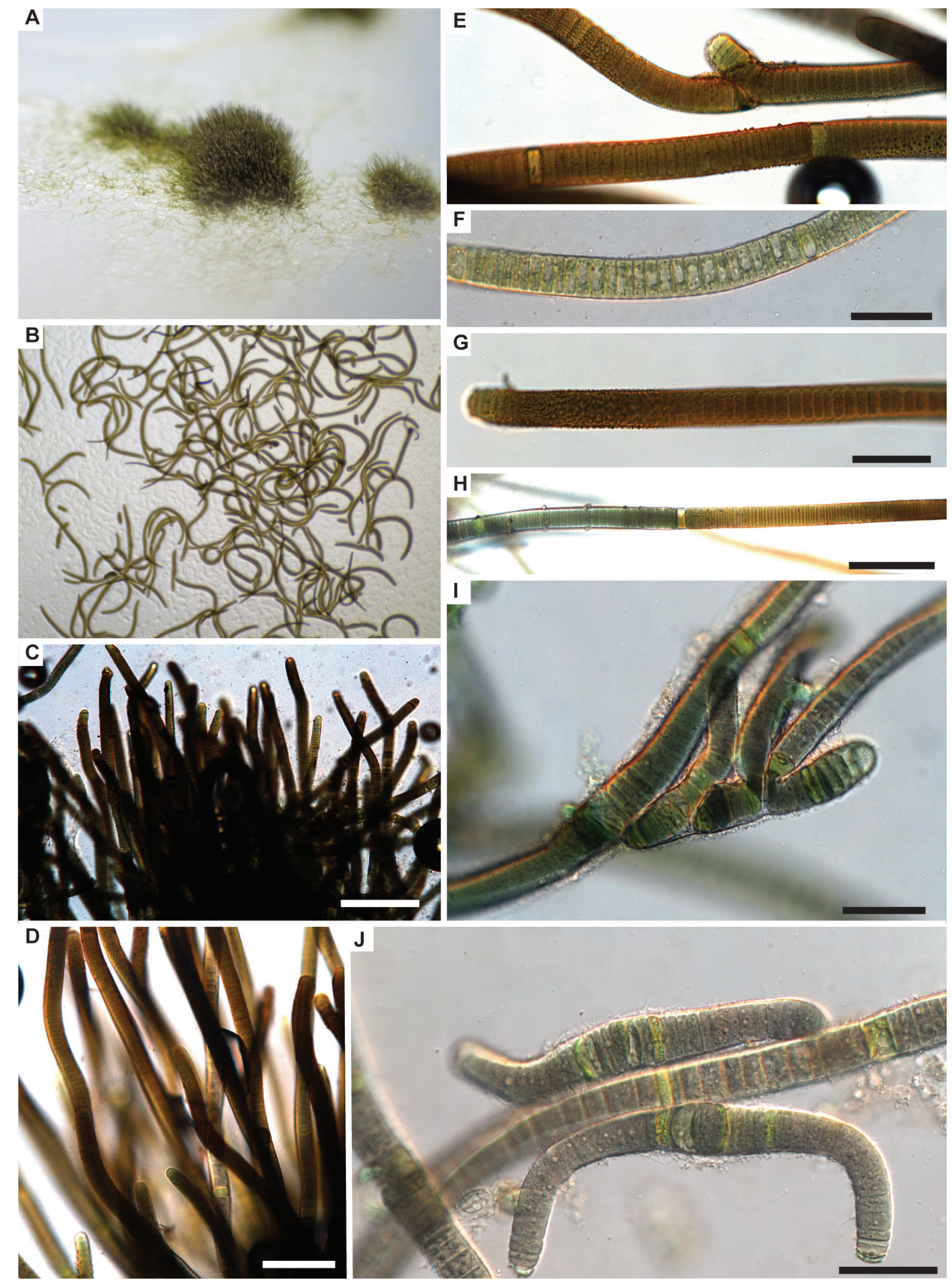

Fig. 3. Images of Brasilonema santannae sp. nov. (reference strain BLCC-T43) showing morphological characteristics including: (A-B) thalli growing on solid agar; (C-D) densely packed filaments; (E,H,J) intercalary heterocytes; (F) cell vacuolization; (E,G) extensive crust-like formation on sheath; (I) Scytonemataceae-type false branching; (I,J) hyaline sheath and attached isopolar motile hormogonia. Scale bars 200 $\mu \mathrm{m}(\mathrm{C}), 100 \mu \mathrm{m}(\mathrm{D}), 50 \mu \mathrm{m}(\mathrm{F}-\mathrm{J})$. 

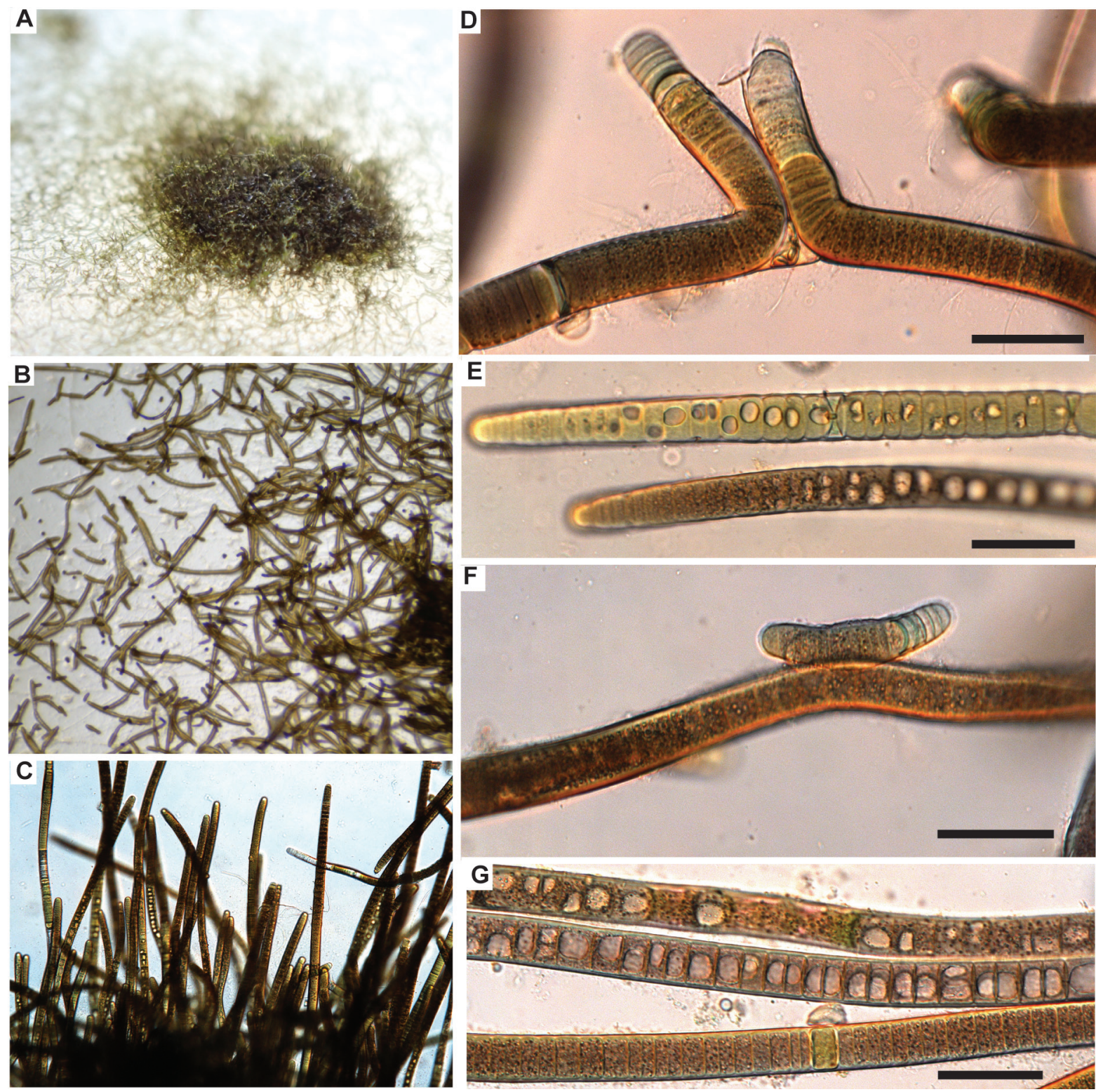

Fig. 4. Images of Brasilonema wernerae sp. nov. (reference strain BLCC-T49) showing morphological characteristics including: (A-B) thalli growing on solid agar; (C) densely fasciculate filaments; (D) double false branching; (E,G) extensive cell vacuolization; (F) isopolar attached hormogonia; (G) intercalary heterocytes. Scale bars $50 \mu \mathrm{m}$ (D-G).

(Suppl. Figs 1-3).

Brasilonema santannae sp. nov. (BLCC-T43 and BLCC-T64) also demonstrated typical characters of the genus Brasilonema; the species is subaerophytic and forms dense erect fascicles (Fig. 3A). The trichomes possess intercalary heterocytes, have sheaths that are often hyaline, or colorless, and form vacuole-like structures (Figs 3F, H, J). False branching is Scytonemataceae-type (Fig. 3I) and hormogonia are motile and isopolar (Fig. $3 \mathrm{~J})$. The morphological feature that distinguishes $B$. santannae from other species in Brasilonema are the extensive crust-like formations on the sheath (Figs 3E, G). Moreover, $B$. santannae differs morphologically from its most closely related taxa $B$. sennae and B. bromeliae by having larger dimensions of filament width, trichome width, and cell length (Suppl. Figs 1-3).

Brasilonema wernerae sp. nov. (BLCC-T49) was also macroscopically typical to the genus Brasilonema with dense erect fascicles and subaerophytic nature (Fig. 4A). The trichomes form intercalary heterocytes, have sheaths that are often hyaline, or colorless, and contain vacuole-like structures (Fig. 4G). False branching is Scytonemataceae-type (Fig. 4D) and hormogonia are isopolar (Fig. 4F). B. santannae differs from all other described Brasilonema by having much larger filament width, trichome width, and cell length (Suppl. Figs 1-3). Moreover, $B$. wernerae is distinguished from sister taxa by larger and more extensive cell vacuolization.

Besides morphology and 16S rRNA gene phylogeny, we examined the percent similarity of the $16 \mathrm{~S}$ rRNA gene between our newly described species and 14 of the most closely related taxa from the phylogenetic analysis (Table 2). Results revealed a similarity of $\sim 99.0 \%$ for strains BLCC-T43 and BLCC-T64, comprising $B$. 

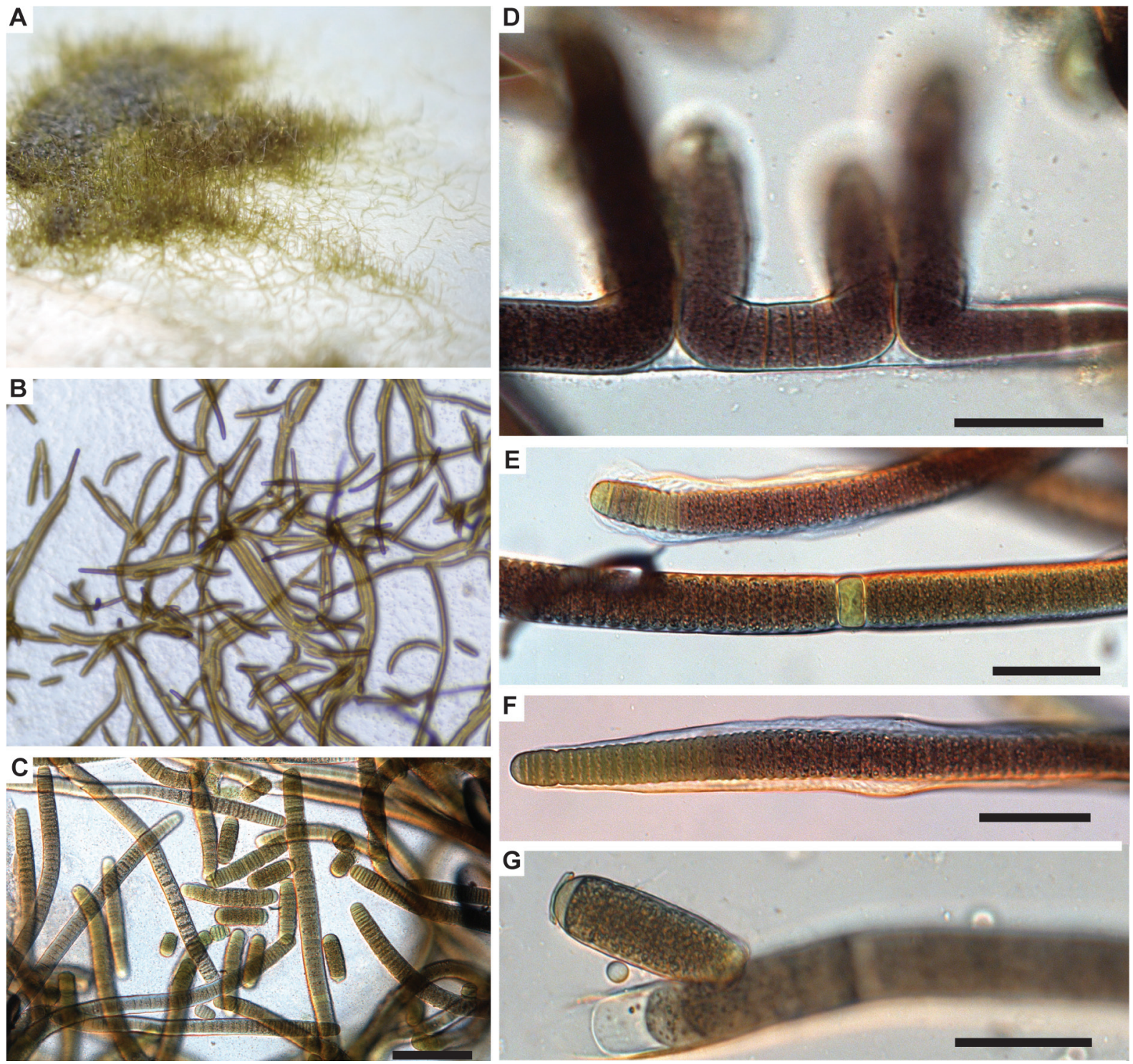

Fig. 5. Images of Brasilonema tolantongensis Becerra-Absalón et Montejano (strain BLCC-T51) showing morphological characteristics including: (A-B) thalli growing on solid agar; (C) darkened cell walls and bent, slightly tapering filament ends; (D) double false branching; (E) intercalary heterocytes and cell granulation; (F) thick lamellate, hyaline sheath; (G) attached hormogonia. Scale bars $200 \mu \mathrm{m}(\mathrm{C}), 50 \mu \mathrm{m}$ (D-G).

santannae. In addition, strain BLCC-T49 had similarities lower than $99.0 \%$ with related taxa, indicating a unique species and described as $B$. wernerae. Strains of $B$. fioreae (BLCC-T72, BLCC-T73, BLCC-T83, and BLCC-T86) were $\sim 99.0 \%$ similar among each other, but also had a similarity $\sim 99.0 \%$ with some $B$. octagenarum strains. Our strains of $B$. tolantongensis (BLCC-T51 and BLCC-T61) and B. octagenarum (BLCC-T71 and BLCC-T74) were $\sim 99.0 \%$ similar to other strains of $B$. tolantongensis and B. octagenarum, respectively.

16S-23S rRNA internal transcribed spacer (ITS) phylogeny, p-distance analyses, and secondary structure Both the 16S-23S rRNA ITS operons with and without tRNAs were recovered from the species examined (Table 3) and a phylogeny was globally constructed. Phylogenetic analyses resulted in ITS sequences with and without tRNAs generally clustering into separate clades. While the clade of sequences containing tRNA was well supported (ML: 79, BS 0.93), those lacking the tRNA sequences formed two unsupported clades (Fig. 8). The $16 \mathrm{~S}-23 \mathrm{~S}$ rRNA ITS phylogeny of our isolates highly correlated with that suggested by the $16 \mathrm{~S}$ rRNA gene phylogeny; B. santannae formed a single wellsupported clade (ML: 100, BS: 1.0), while B. fioreae formed two well-supported clades, based on presence or absence of tRNA (ML: 70, BS: 0.93; ML: 99, BS: 0.98; respectively) (Fig. 8). Brasilonema wernerae and B. tolantongensis BLCC-T61, both possessing tRNA, formed a well-supported clade (ML: 99, BS: 1.00); however, B. tolantongensis (BLCC-T51) also produced another subclade alone (ML: 65, BS:-).

We examined the percent dissimilarity of the 16S-23S rRNA ITS region between our newly described 

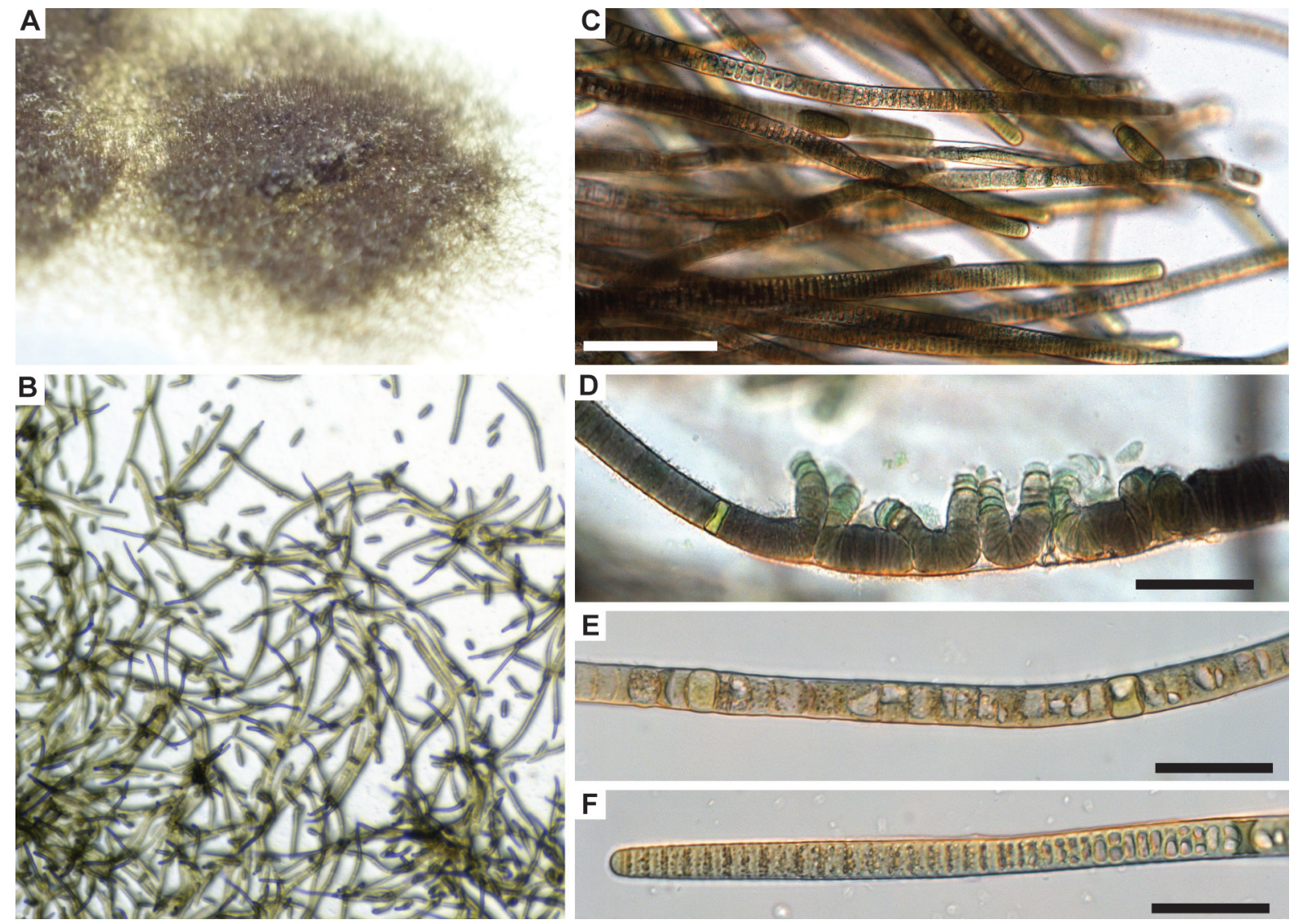

Fig. 6. Microscopic images of Brasilonema octagenarum Aguiar, Fiore, Franco, Ventrella, Lorenzi, Vanetti et Alfenas (strain BLCC-T71) showing morphological characteristics including: (A-B) thalli growing on solid agar; (C) fasciculate filaments and hormogonia; (D) Tolypothrichaceae-type false-branching; (E-F) cell vacuolization and intercalary heterocytes. Scale bars $100 \mu \mathrm{m}(\mathrm{C}), 50 \mu \mathrm{m}(\mathrm{D}-\mathrm{F})$.

species and five other 16S-23S rRNA ITS sequences from previously described species of Brasilonema (Table 4). Genetic dissimilarities resulted in $0.15 \%$ dissimilarity in B. santannae (BLCC-T43 and BLCC-T64). Brasilonema wernerae $\mathrm{BLCC}-\mathrm{T} 49$ and $B$. tolantongensis $\mathrm{BLCC}-\mathrm{T} 61$ had a dissimilarity of $0.71 \%$, while $B$. fioreae (BLCC-T72 and BLCC-T83) showed $0.0 \%$ dissimilarity. Results also revealed a dissimilarity of greater than $8 \%$ between the rest of our strains and a dissimilarity of greater than $10 \%$ between all our strains and other species of Brasilonema. Secondary structures (D1-D1' helix and the Box-B helix) of the $16 \mathrm{~S}-23 \mathrm{~S}$ ITS regions were compared between the 11 isolates that belong to five species and other published sequences. The D1-D1' helices displayed nine distinct structures with varying sequences and length between all the strains (Fig. 9). Brasilonema santannae (BLCC-T43 and BLCC-T64) demonstrated identical structures and base pairs among isolates (Fig. 9a). Brasilonema wernerae BLCC-T49 and B. tolantongensis BLCC-T61 shared the same general structure but with different base pairs within the terminal bulb (Figs. $9 \mathrm{~b}, \mathrm{~d})$. Brasilonema tolantongensis BLCC-T51 formed a comparatively unique structure (Fig. 9c). Brasilonema octagenarum BLCC-T71 formed an identical structure to B. octagenarum BLCC-T74 (Fig. 9e, f). Brasilonema fioreae BLCC-T73 (Fig. 9h) formed a similar structure to $B$. fioreae (BLCC-T72 and BLCC-T83) (Fig. 9g) but with differing base pairs in the terminal bulb, while $B$. fioreae BLCC-T86 (Fig. 9i) was similar to B. fioreae BLCC-T73 but with differing base pairs resulting in two bulges in the stem rather than a single bulb. From the eleven isolates examined, no isolates shared similar D1-D1' structures with other Brasilonema species.

The Box-B region revealed 8 structures with similar lengths and configuration but with varying sequences among all the strains (Fig. 10). Strains of B. santannae (BLCC-T43 and BLCC-T64) shared identical structures and sequence (Fig. 10a). Brasilonema wernerae BLCCT49 and B. tolantongensis BLCC-T61 (Figs. 10b, d) also had the same structure and sequence. Brasilonema tolantongensis BLCC-T51 (Fig. 10c) possessed a similar structure to B. wernerae BLCC-T49 (Fig. 10b) and $B$. tolantongensis BLCC-T61 (Fig. 10d), but with differing sequences. Brasilonema octagenarum BLCC-T71 (Fig. 10e) formed a similar structure to B. santannae (Fig. 10a) but base pairs differed. Brasilonema fioreae (BLCC-T72 and BLCC-T83; Fig. 10g) was similar to B. santannae (BLCC-T43 and BLCC-T64; Fig. 10a) and Brasilonema octagenarum BLCC-T71 (Fig. 10e). Brasilonema fioreae (BLCC-T73 and BLCC-T86) (Figs. 10h, i) and B. octagenarum BLCC-T74 (Fig. 10f) shared similar structures, as well as, but with differing sequences. 


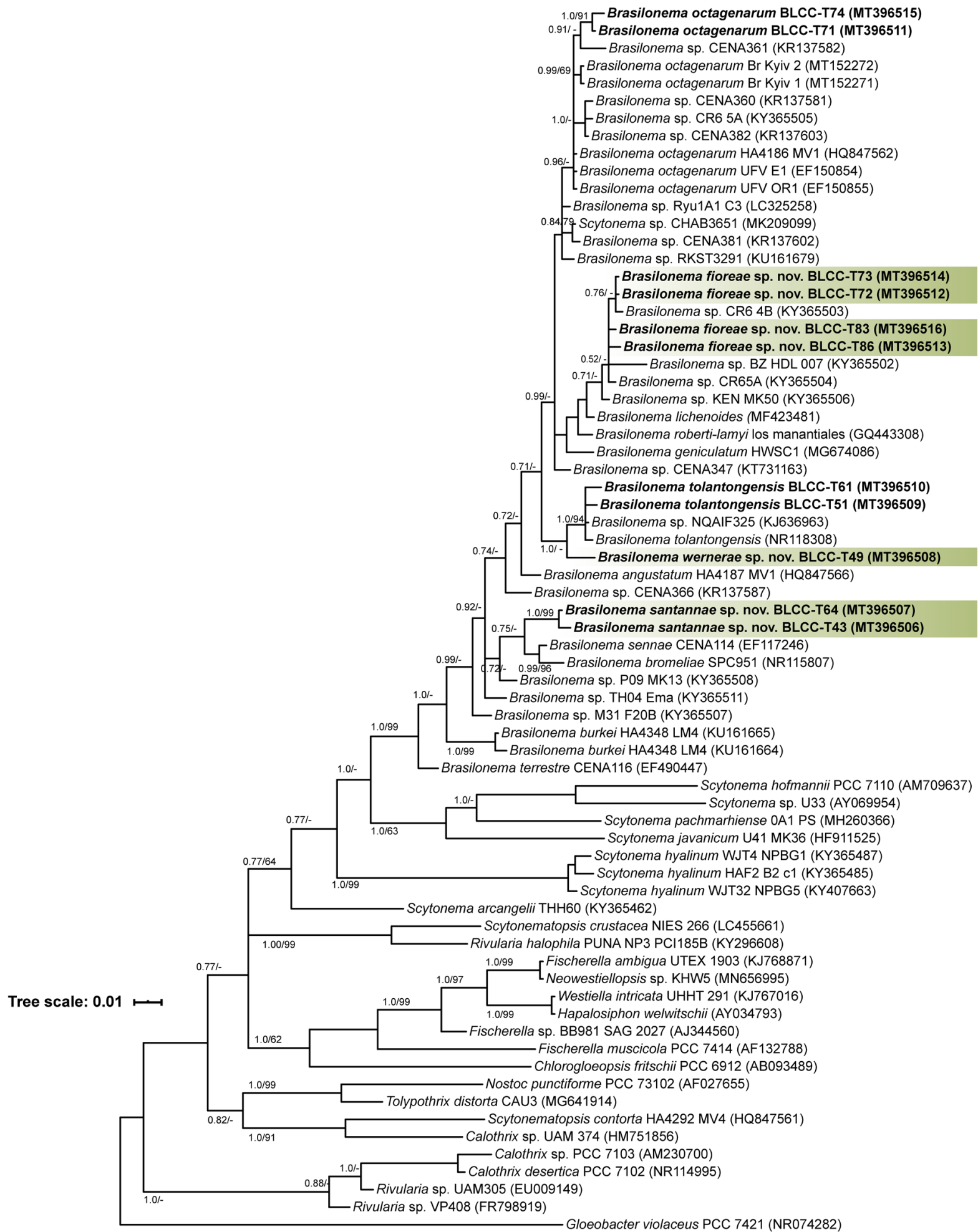

Fig. 7. Bayesian inference phylogenetic tree showing the relationship of the $16 \mathrm{~S}$ rRNA gene sequence representative of 11 cyanobacterial species isolated in this work and 59 cyanobacterial species including Gleobacter violaceous (NR074282) as an outgroup. Maximum likelihood bootstrap support and Bayesian posterior probabilities $\geq 50$ and 0.5 are shown at nodes, respectively.

\section{DiscUSSION}

Based on morphological, molecular, and phylogenetic data we discovered a total of five species of Brasilonema, including three new species to science within plant nursery and greenhouse areas (Fig. 1). The taxa described in this paper conform to the generic characteristics of Brasilonema (Table 1, Table S2). Specifically, phylogenetic analyses of the 16 rRNA gene showed the inclusion of all of the described taxa into the Brasilonema clade with high support (BS:1.0; ML: 87). Molecular phylogenetic 


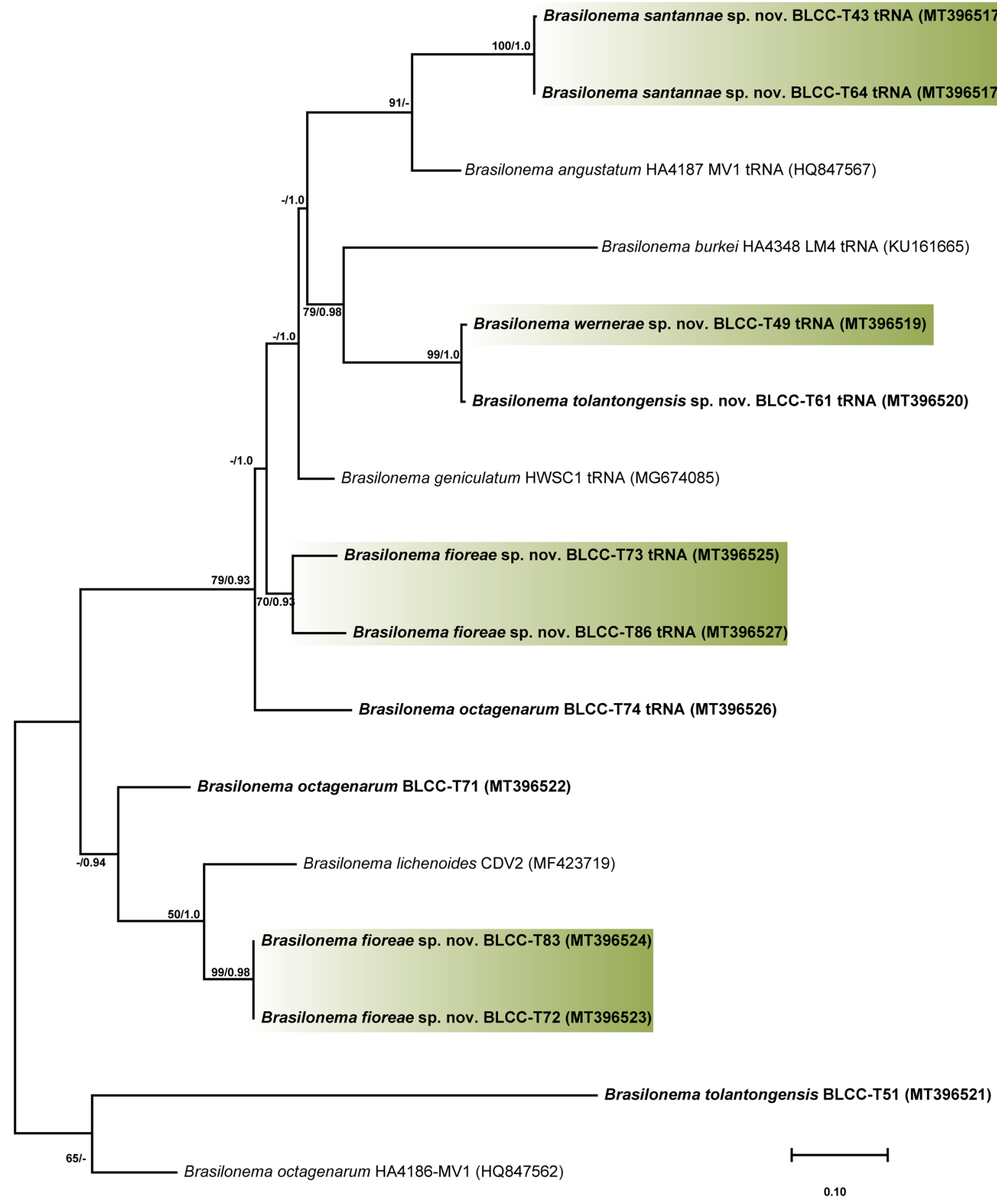

Fig. 8. Bayesian inference and Maximum likelihood phylogenetic relationship of the 16S-23S rRNA gene ITS (internal transcribed spacer) sequence representative of 11 cyanobacterial species isolated in this work and 5 closely related cyanobacterial species. Operons with/without tRNA are included in tree. Maximum likelihood bootstrap support and Bayesian posterior probabilities $\geq 50$ and 0.5 are shown at nodes, respectively.

evidence also supports the proposal of three new species, B. fioreae, B. santannae, and B. wernerae, with previously described Brasilonema species. To fully appreciate the diversity among the isolates and to clearly delimitate the proposed species, applying the polyphasic method was necessary.

Both the 16S rRNA gene and the 16S-23S rRNA ITS region phylogenies suggest the erection of three new species (Figs 7, 8). The secondary structure of the D1-D1' region of the 16S-23S rRNA ITS region also greatly supported the delimitation of the proposed species based on configuration (Fig. 9). The genetic dissimilarities of sequences of the 16S-23S rRNA ITS region were greater than $10 \%$ for the different species, which further supported these novel species (GoNZÁLEZ-RESENDIZ et al. 2019). Morphological data indicated that critical 

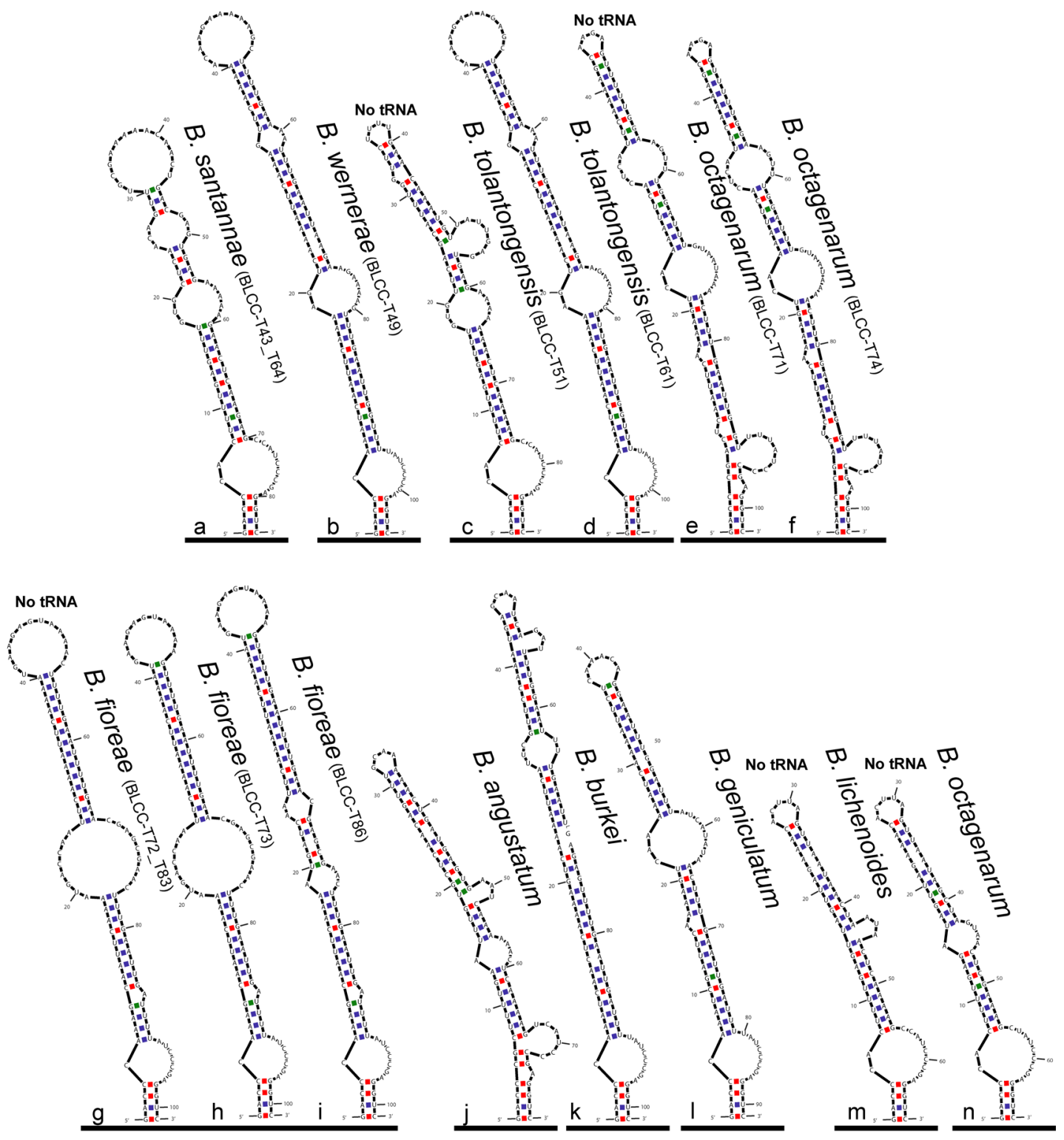

Fig. 9. Secondary structures of the D1-D1' helices from the 16S-23S rRNA ITS regions of 11 isolates and closest relatives from Brasilonema for which 16S-23S rRNA ITS sequence data are available: (a) B. santannae (BLCC-T43 and BLCCT64); (b) B. wernerae (BLCC-T49); (c) $B$. tolantongensis (BLCC-T51) (no tRNA); (d) B. tolantongensis (BLCC-T61); (e) B. octagenarum (BLCC-T71) (No tRNA); (f) B. octagenarum (BLCC-T74); (g) B. fioreae (BLCC-T72 and BLCC-T83) (no tRNA); (h) B. fioreae (BLCC-T73); (i) B, fioreae (BLCC-T86); (j) B. angustatum; (k) B. burkei; (1) B. geniculatum; (m) B. lichenoides (no tRNA); (n) B. octagenarum (no tRNA).

characteristics of each new species used for delimitation include crust-like texture of the sheath of $B$. santannae, large cell vacuoles of $B$. fioreae, and the relatively large cell dimensions of $B$. wernerae.

From the 16S-23S rRNA ITS phylogeny, we found that $B$. wernerae BLCC-T49 clustered with a sequence of B. tolantongensis BLCC-T61 (Fig. 8). It was also observed that the $16 \mathrm{~S}-23 \mathrm{~S}$ rRNA ITS D1-D1' secondary structure of strains of $B$. tolantongensis (BLCC-T51 and BLCC-T61; Figs 9c, d) and B. fioreae (BLCC-T72, BLCC-T83, BLCC-T73, and BLCC-T86; Figs 9g-i) were variable resulting with two different structures each. Together with the little variation observed among the Box B secondary structures (Fig. 10) of Brasilonema species, it is evident that multiple lines of evidence are crucial to properly identify these species. Though there was much overlap in molecular and morphological characteristics, the combination of all the molecular and morphological data support the five species found, including the three novel species proposed: B. fioreae, $B$. santannae and $B$. wernerae.

This paper is also the first record of B. tolantongensis and B. octagenarum in the continental USA. The existence of five different species of Brasilonema co-occurring in plant nurseries may be attributed to the commercial trade of ornamental plants. Ornamental plant trade among greenhouses and nurseries is widespread (REICHARD \& WhITE 2001; BRADLEY et al. 2012) and this trade is evident by the occurrence of $B$. tolantongensis and $B$. octagenarum in Florida, which were originally 


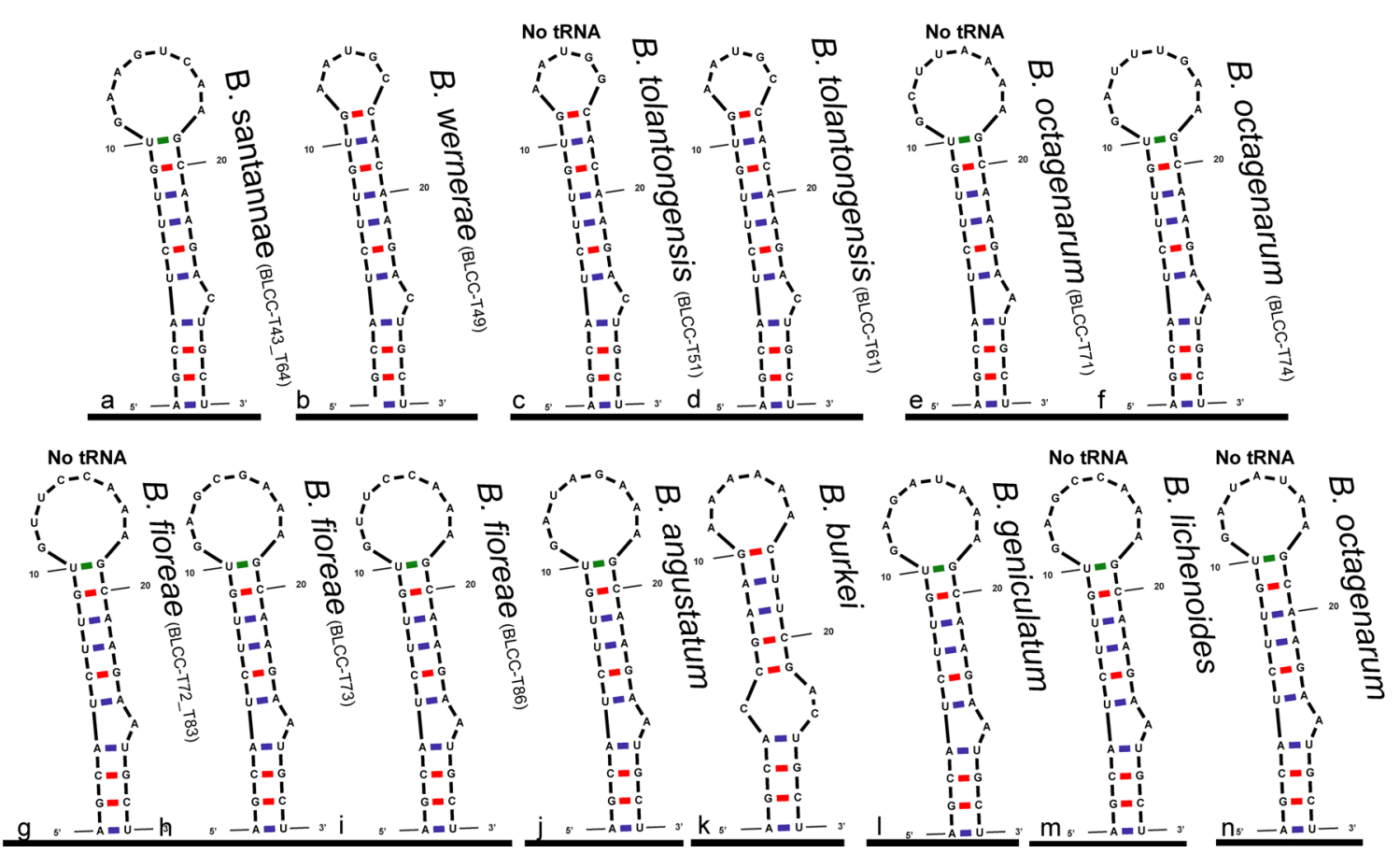

Fig. 10. Secondary structures of the Box-B region from the 16S-23S rRNA ITS regions of 11 isolates and closest relatives from Brasilonema for which 16S-23S rRNA ITS sequence data are available: (a) B. santannae (BLCC-T43 and BLCCT-64); (b) B. wernerae (BLCC-T49); (c) B. tolantongensis (BLCC-T51) (no tRNA); (d) B. tolantongensis (BLCC-T61); (e) B. octagenarum (BLCC-T71) (no tRNA); (f) B. octagenarum (BLCC-T74); (g) B. fioreae (BLCC-T72 and BLCC-T83) (no tRNA); (h) B. fioreae (BLCC-T73); (i) B, fioreae (BLCC-T86); (j) $B$. angustatum; (k) B. burkei; (1) B. geniculatum; (m) B. lichenoides (no tRNA); (n) B. octagenarum (no tRNA).

described from Mexico and Brazil, respectively, and the occurrence of Brasilonema in a tropical greenhouse in Ukraine (ROMANENKo et al. 2020). Additionally, B. octagenarum could potentially be invasive and a potential threat for horticulture as this species has been observed to damage the leaves of Eucalyptus plants (AGUIAR et al. 2008; Alvarenga et al. 2020). Until now, B. tolantongensis had only been described in its type location Hidalgo, Mexico, thus the occurrence in Florida shows that this species is potentially more widespread than originally thought. Furthermore, a strain from Australia, Brasilonema sp. NQAIF325 (KJ636963), also clusters with this species, suggesting that $B$. tolantongensis is more widespread in (sub)tropical regions.

Greenhouses used as nurseries for growing tropical and agricultural plants make ideal habitats for the development of subaerophytic cyanobacteria, biofilms, and microbial mats (AGUiAR et al. 2008; LAUGHINGHOUSE et al. 2019; RomanenKo et al. 2020; Berthold et al. 2021). Their warm temperature, high moisture, and relatively stable environmental setting provides optimal conditions for the growth of cyanobacteria (including Brasilonema) and other algae that can become a nuisance. The high diversity of Brasilonema found in the studied greenhouses suggests that these production areas may be a potential 'hotspot' of cyanobacterial diversity. Overall, Brasilonema is a genus of cryptic cyanobacteria containing species with much overlap in morphology, molecular phylogeny, and habitat and combined molecular and morphological scrutiny are indispensable in deciphering and describing species.

\section{ACKNOWLEDGEMENTS}

The authors would like to thank Dr. Mike Wynne for nomenclatural assistance. This work was partially supported by the US Department of Agriculture - National Institute of Food and Agriculture Hatch project \#FLA-FTL-005697; Florida Nursery, Growers, and Landscape Association (FNGLA) Endowed Research Fund at the University of Florida/IFAS; and the Florida Sea Grant College Program of the U.S. Department of Commerce's National Oceanic and Atmospheric Administration (NOAA), Grant No. NA 18OAR4170085. The views expressed are those of the authors and do not necessarily reflect the views of these organizations.

\section{REFERENCES}

Aguiar, R.; Fiore, M.F.; Franco, M.W.; Ventrella, M.C.; Lorenzi, A.S.; VAnetTi, C.A. \& Alfenas, A.C. (2008): A novel epiphytic cyanobacterial species from the genus Brasilonema causing damage to Eucalyptus leaves. Journal of Phycology 44: 1322-1334.

Alvarenga, D.O.; Franco, M.W.; Sivonen, K.; Fiore, M.F. \& VARANI A.M. (2020): Evaluating Eucalyptus leaf colonization by Brasilonema octagenarum (Cyanobacteria, Scytonemataceae) using in planta experiments and genomics. - PeerJ 8: e9158

Becerra-Absalón, I.; Rodarte, B.; Osorio, K.; Alba-Lois, L.; Segal-KischinevzKy, C. \& Montejano, G. (2013): A new species of Brasilonema (Scytonemataceae, Cyanoprokaryota) from Tolantongo, Hidalgo, Central Mexico. - Fottea 13: 25-38.

Berthold, D.E.; Elazar, A.; Lefler, F.; Marble, S.C. \& Laughinghouse IV, H.D. (2021): Control of algal 


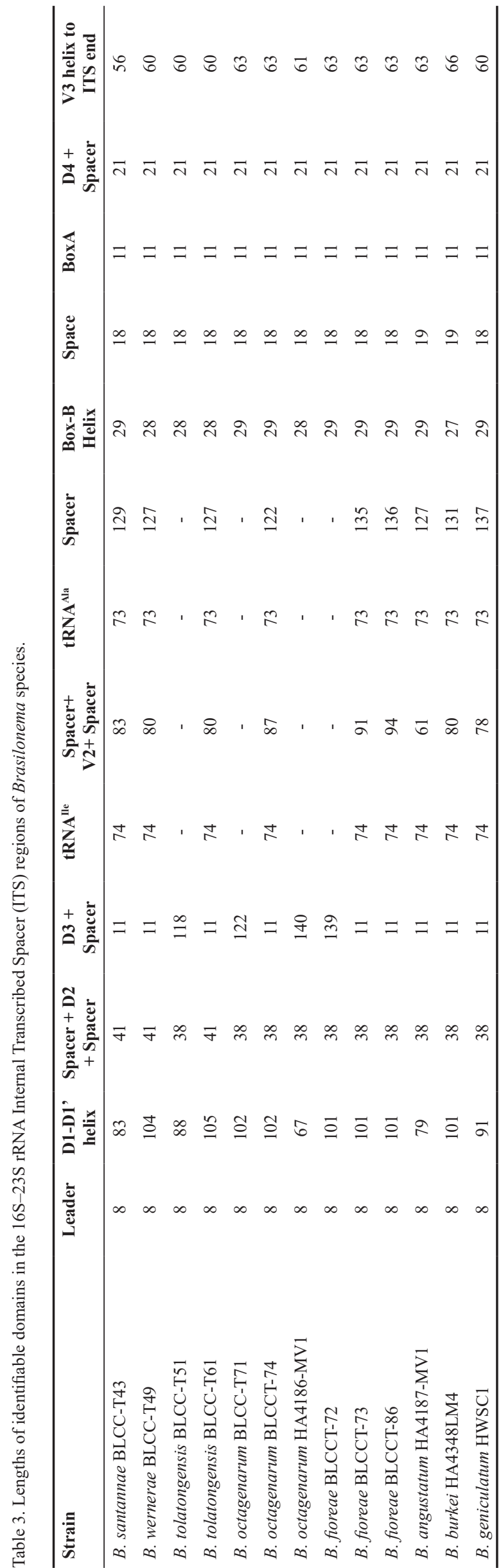

growth on greenhouse surfaces using commercial algaecides. - Scientia Agricola 78: e20180292. DOI: 10.1590/1678-992X-2018-0292.

Berthold, D.E.; LeFLer, F.W.; Werner, V.R. \& LAUGHINGHOUSE IV, H.D. (2020): Johannesbaptistia floridana sp. nov. (Chroococcales, Cyanobacteria), a novel marine cyanobacterium from coastal South Florida (USA). - Fottea 20: 152-159. DOI: 10.5507/fot.2020.008.

Bradley, B.A.; Blumenthal, D.M.; Early, R.; Grosholz, E.D.; Lawler, J.J.; Miller, L.P.; Sorte, C.J.B.; D’Antonio, C.M.; Diez, J.M.; Dukes. J.S.; IBANez, I. \& OldEN, J.D. (2012): Global Change, Global Trade, and the next Wave of Plant Invasions. - Frontiers in Ecology and the Environment 10: 20-28.

Dvořák, P.; JahodÁŘová, E.; CASAMatTa, D.A.; HašLer, P. \& PoulíčKová, A. (2018): Difference without distinction? Gaps in cyanobacterial systematics; when more is just too much. - Fottea 18: 130-136. DOI: $10.5507 /$ fot.2017.023

EDGAR, R.C. (2004): MUSCLE: multiple sequence alignment with high accuracy and high throughput. - Nucleic Acids Research 32: 1792-1797.

Fiore, M.F.; SANT'AnNa, C.L.; Azevedo, M.T.D.P.; KomÁReK, J.; KAŠTovSKÝ, J.; SULEK, J. \& LORENZI, A.S. (2007): The cyanobacterial genus Brasilonema gen. nov., a molecular and phenotypic evaluation. - Journal of Phycology 43: 789-798.

Gama JR., W.A; Laughinghouse IV, H.D. \& Sant'Anna, C.L. (2014): How diverse are coccoid cyanobacteria? A case study of terrestrial habitats from the Atlantic Rainforest (São Paulo, Brazil). - Phytotaxa 178: 61-97.

GonZÁLEZ-Resendiz, L.; Johansen, J.R.; León-TeJera, H.; SÁNCHEZ, L.; SEgAL-KischineVZKY, C.; EscobaRSÁnchez, V. \& Morales, M. (2019): A bridge too far in naming species: a total evidence approach does not support recognition of four species in Desertifilum (Cyanobacteria). - Journal of Phycology 55: 898-911.

Guindon, S. \& GASCuEL, O. (2003): A simple, fast, and accurate algorithm to estimate large phylogenies by maximum likelihood. - Systematic Biology 52: 696-704.

KomÁreK, J.; KaštovskÝ, J.; Mareš, J. \& Johansen, J.R. (2014): Taxonomic classification of cyanoprokaryotes (cyanobacterial genera) 2014, using a polyphasic approach. - Preslia 86: 295-335.

KoMÁREK, J. (2016): A polyphasic approach for the taxonomy of cyanobacteria: principles and applications. - European Journal of Phycology 51: 346-353.

Kumar, S.; Stecher, G.; Li, M.; Knyaz, C. \& Tamura, K. (2018): MEGA X: molecular evolutionary genetics analysis across computing platforms. - Molecular Biology and Evolution 35: 1547-1549.

Laughinghouse IV, H.D.; Berthold, D.E.; Marble, C. \& SAHA, D. (2019): Biology and Management of Nostoc (Cyanobacteria) in Nurseries and Greenhouses. SS-AGR-431. - Gainesville: University of Florida Institute of Food and Agricultural Sciences, https:// edis.ifas.ufl.edu/ag430.

Miller, M.A.; Pfeiffer, W. \& Schwartz, T. (2010): "Creating the CIPRES Science Gateway for inference of large phylogenetic trees". - In: Proceedings of the Gateway Computing Environments Workshop (GCE), 14 Nov. 2010. - pp. $1-8$, New Orleans, LA. DOI: 10.1109 / GCE.2010.5676129.

Miscoe, L.H.; Johansen, J.R.; Vaccarino, M.; Pietrasiak, N. \& SHERwoOd, A.R. (2016): Novel cyanobacteria from 
caves on Kauai, Hawaii. - Bibliotheca Phycologica 120: 75-152.

Montoya, H.; Gómez, J.; Mariano M.; Jara, E; \& MAYTA, E. (2019): Variabilidad fenotípica de la cianobacteria Brasilonema (Nostocales, Scytonemataceae) en comunidad aerofítica, nuevo registro para el Perú. - Arnaldoa 26: 643-656.

NÜBel, U.; Garcia-Pichel, F. \& Muyzer, G. (1997): PCR primers to amplify $16 \mathrm{~S}$ rRNA genes from cyanobacteria. - Applied and Environmental Microbiology 63: 3327-3332.

Pessi, I.S.; Maalouf, P.C.; Laughinghouse IV, H.D.; Baurain, D. \& Wilmotte, A. (2016): On the use of high-throughput sequencing for the study of cyanobacterial diversity in Antarctic aquatic mats. - Journal of Phycology 52: 356-368.

Pietrasiak, N.; Osorio-Santos, K.; Shalygin, S.; Martin, M.P. \& Johansen, J.R. (2019): When Is A Lineage A Species? A Case Study in Myxacorys gen. nov. (Synechococcales: Cyanobacteria) With The Description of Two New Species From The Americas. Journal of Phycology 55: 976-996.

ReichaRD, S.H. \& White, P. (2001): Horticulture as a Pathway of Invasive Plant Introductions in the United States: Most invasive plants have been introduced for horticultural use by nurseries, botanical gardens, and individuals. - BioScience 51: 103-113.

Rodarte, B.; Becerra-Absalón, I.; Montejano, G.A.; Osorio-SANTOS, K.; Alba-LoIs, L.; LeÓN-TeJERA, H. \& SEGAL-KischineVZKY, C. (2014): Morphological and molecular characterization of Brasilonema roberti-lamii (Cyanophyceae, Nostocales, Scytonemataceae), from Central Mexico. - Phytotaxa 164: 255-264.

RomanenKo, P.A.; VinOGRADOVA, O.N.; ROMANENKO, E.A.; MikhailyuK, T.I.; BabenKo, L.M.; IVANNIKOV, R. \& SCHERBAK, N.N. (2020): Morphological and molecular characterization of the representative of Brasilonema (Scytonemataceae, Cyanoprokaryota) from the tropical greenhouse in Kiev (Ukraine). - International Journal on Algae 22: 103-122.

Ronquist, F. \& HuELSENBECK, J.P. (2003): MrBayes 3: Bayesian phylogenetic inference under mixed models. - Bioinformatics 19: 1572-1574.

Sant'Anna, C.L.; Azevedo, M.T.P.; Fiore, M.F.; LoRenZI, A.S.; KAŠTOVSKÝ, J. \& KomáreK, J. (2011): Subgeneric diversity of Brasilonema (Cyanobacteria, Scytonemataceae). - Revista Brasileira de Botânica 34: 51-62.

Stecher, G.; TAmura, K. \& Kumar, S. (2020): Molecular evolutionary genetics analysis (MEGA) for macOS. - Molecular Biology and Evolution 37:1237-1239.

VACCARINO, M.A. \& JohAnSEn, J.R. (2012): Brasilonema angustatum sp. nov. (Nostocales), a new filamentous

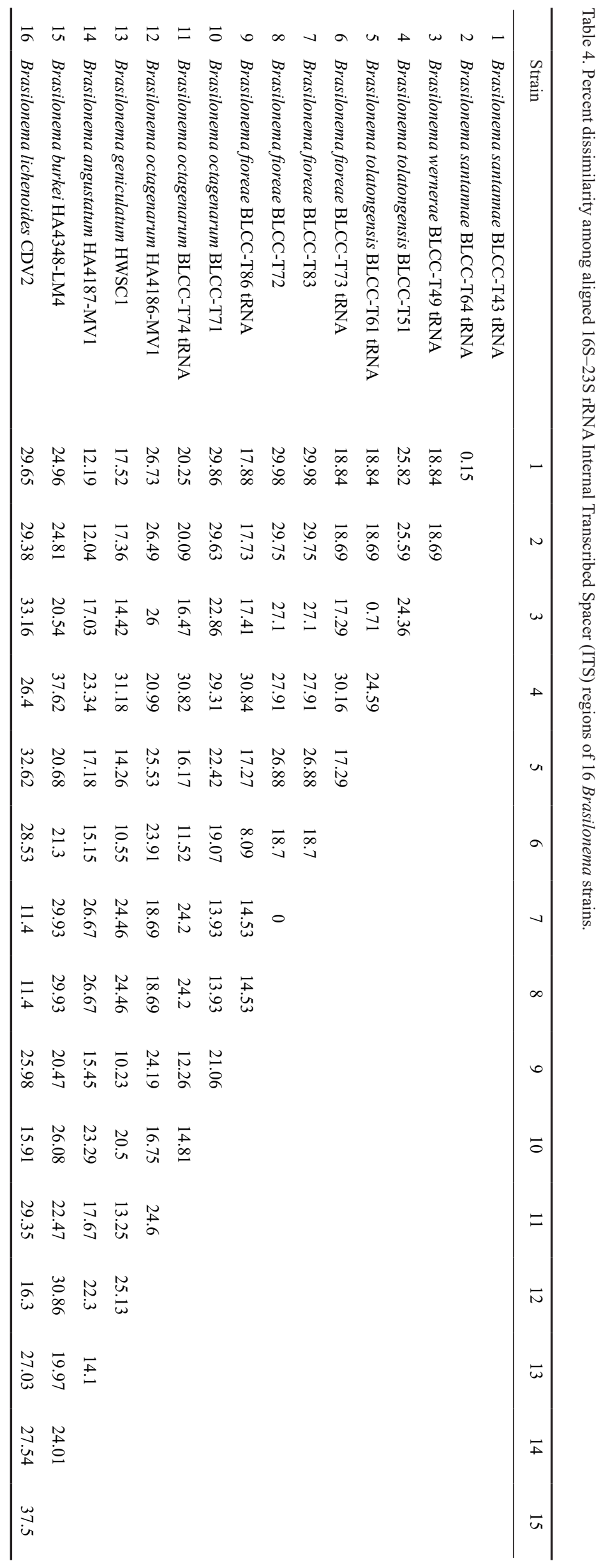


cyanobacterial species from the Hawaiian Islands. Journal of Phycology 48: 1178-1186.

Villanueva, C.D.; Garvey, A.D.; Hašler, P.; Dvořák, P.; Poluíč́Ková, A.; Norwich, A.R. \& CASAmatTa, D.A. (2019): Descriptions of Brasilonema geniculatum and Calothrix dumus (Nostocales, Cyanobacteria): two new taxa isolated from cemetery tombstones. - Phytotaxa 387: $1-20$.

Villanueva, C.D.; HašLer, P.; DvořáK, P.; PoluíčKová, A. \& CASAmatTA, D.A. (2018): Brasilonema lichenoides sp. nov. and Chroococcidiopsis lichenoides sp. nov. (Cyanobacteria): two novel cyanobacterial constituents isolated from a tripartite lichen of headstones. - Journal of Phycology 54: 224-233.

Whitton, B.A. \& Potts, M. (2012): Introduction to the Cyanobacteria. - In: Whitton, B.A. \& Potts, M. (eds): Ecology of cyanobacteria II: their diversity in space and time. - pp. 1-13, Springer, Dordrecht.

Wilmotte, A.; Laughinghouse IV, H.D.; Capelli, C.; Rippka, R. \& SAlmaso, N. (2017): Taxonomic identification of Cyanobacteria by a polyphasic approach. - In: KURMAYER, R.; Sivonen, K.; Wilmotte, A. \& Salmaso, N. (eds): A Handbook on Molecular Tools for the Detection and Quantification of Toxigenic Cyanobacteria. - pp.79-119, Wiley, Hoboken, NJ (USA).

Wilmotte, A.; Van der Auwera, G. \& De Wachter, R. (1993): Structure of the 16S ribosomal RNA of the thermophilic cyanobacterium Chlorogloeopsis HTF ('Mastigocladus laminosus HTF') strain PCC7518, and phylogenetic analysis. - FEBS Letters 317: 96-100.

ZuKER, M. (2003): Mfold web server for nucleic acid folding and hybridization prediction. - Nucleic Acids Research 31: 3406-3415.
Supplementary material

The following supplementary material is available for this article:

Table S1. Cyanobacterial strain information including voucher numbers of type material, strain numbers of live cultures, and accession numbers genetic information.

Table S2. Comparison of generic and specific morphological characteristics of several representative species within the genus Brasilonema, extended.

Fig. S1. Filament width $(\mu \mathrm{m})$ boxplot of 11 isolates from this study, grouped into species, and closest relatives from Brasilonema for which filament width data was available.

Fig. S2. Trichome width $(\mu \mathrm{m})$ boxplot of 11 isolates from this study, grouped into species, and closest relatives from Brasilonema for which trichome width data was available.

Fig. S3. Cell length $(\mu \mathrm{m})$ boxplot of 11 isolates from this study, grouped into species, and closest relatives from Brasilonema for which cell length data was available.

This material is available as part of the online article (http:// fottea.czechphycology.cz/contents)

(C) Czech Phycological Society (2021)

Received July 27, 2020

Accepted December 1, 2020 